\title{
Active Listening as A Basic Skill of Efficient Communication Between Teachers and Parents: An Empirical Study
}

\author{
Maria E. Chatzinikola
}

ABSTRACT

\begin{abstract}
This study deals with active listening as a basic skill of efficient communication used by teachers in their communication with their students' parents. Two hundred and twenty-two teachers and thirty-three principals of primary education school units participated in this empirical study. Teachers mention that they use active listening in their communication with parents with attention and observation, they accept parents' words, they maintain a neutral position and they show empathy to share their reflections and feelings. Moreover, during the use of active listening as an active skill of efficient communication between teachers and parents, teachers mention the contribution of their verbal intervention. In this way they ask open-ended and closed-ended questions for clarifications, and they repeat the parent's main views without expressing their personal opinion. During their verbal positioning, teachers first mention to parents the good characteristics of their children, then they focus on their learning weaknesses.
\end{abstract}

Keywords: Active listening, communication skills, parents, teachers, verbal intervention.

\section{INTRODUCTION}

Communication is one of the learning skills of the $21^{\text {st }}$ century. Together with critical thinking, cooperation, and creativity, they shape the teaching environment of an education system to prepare children appropriate for their future professional life [1]. Thus, the use of communication skills is a basic strategy for the correct communication behavior for students, teachers, and parents. The use of basic communication skills between teachers and parents reinforces students' school performance [2] and the relationships of mutual trust among students, teachers, and parents [3]. In addition, it establishes a positive atmosphere and proper functioning of the school unit [4], contributing to its efficiency [5].

Reference [6] stress the importance not only of two-way communication between teachers and parents, but also the importance of active listening applied by teachers. "Listening is an essential life skill" [7]. The use of active listening skills by teachers as a basic skill of efficient communication between teachers and parents is the first step for the creation of a two-way interpersonal communication and cooperation with their students' parents [8], [9]. Within the framework of efficient communication between teachers and parents, when teachers apply active listening, parents are involved in their children's learning process at school and teachers collect information about the child [10], [11]. This leads to a successful cooperation between school and parents [12].

According to [13], when applying active listening as a
Published Online: November 03, 2021

ISSN: $2736-4534$

DOI : $10.24018 /$ ejedu.2021.2.6.186

M. E. Chatzinikola *

Department of Sciences of Preschool Education and Educational Design, University of the Aegean, Greece. (e-mail: mar.xatzi70@gmail.com)

*Corresponding Author basic skill of efficient communication between teachers and parents, a communicative teacher listens very attentively to the students' parents and shows his/her interest in their opinion by observing. The teacher acknowledges and accepts the parent's views, without correcting the parent's expression and critical positioning [14]. Absence of judgment does not mean that the parent's positioning is correct or that whatever is being said by the parent corresponds to reality. But as the parent speaks, no ideas or suggestions that the parent is not in a position to adopt should be opposed. Acceptance releases the parent, because the parent feels that he/she is talking to a teacher who is really interested in listening to the parent, with authenticity and empathy. Authenticity refers mainly to the neutral position adopted by the teacher during the active listening. Although the teacher has his/her own opinions, experiences, reflections, and feelings governing his/her cultural capital, he/she does not interrupt the parent to express them, but he/she continues listening. Different experiences can lead us to a different perspective [15]. Empathy is a parameter of emotional intelligence. The teacher puts himself/herself in the position of parents, to understand what and how they think, what they wish to say and why they say it [16].

In the development of active listening, the teacher's verbal intervention takes an important position, which relies on specific techniques: a) Open-ended or closed-ended clarification questions, which help the parent unravel his/her thoughts, b) Repetition of some phrases. The teacher mainly repeats the most important opinions of the parent to ensure 
continuity of communication, offering feedback to the communication c) A summary of what he/she listened to, focusing on the main points, without expressing a personal opinion. d) Verbal expression of the parent's feelings. The teacher tries to transmit the parent's feelings in words, applying thus the empathy process. The parent perceives that the teacher not only listens to him/her, but the teacher also understands him/her [13].

Reference [9],[17] mention as active listening skills the strategy LAFF Don't CRY, which offers a basic tool for the efficient communication between teachers and parents [18]. The expression 'LAFF Don't CRY' is an acronym resulting from the initials of English phrases, which encourage teachers to a) listen to parents with empathy and respect, b) ask parents questions while asking for their permission to take notes, c) focus on the communication issue and d) find a first communication step. It also prevents teachers from a) criticizing people who are not present, $b$ ) reacting hastily and promising something they cannot deliver and c) chattering saying incorrect things (Table I):

TABLE I: ‘LAFF DON’T CRY’ REMINDS TEACHERS OF THE WAY IN WHICH THEY SHOULD LISTEN ATTENTIVELY TO PARENTS [17]

\begin{tabular}{cc}
\hline \hline $\mathrm{L}$ & Listen, empathize, and communicate respect \\
$\mathrm{A}$ & Ask questions and ask permission to take notes \\
$\mathrm{F}$ & Focus on the issues \\
$\mathrm{F}$ & Find a first step \\
\hline
\end{tabular}

$\begin{array}{cc}\frac{\text { Don't }}{\mathrm{C}} & \text { Criticize people who aren't present } \\ \mathrm{R} & \text { React hastily and promise something you can't deliver } \\ \mathrm{Y} & \text { Yakety-yak-yak }\end{array}$

\section{Methodology}

The goal of this study is to investigate the views of principals and teachers at multi-classroom primary schools of Rhodes on active listening as a basic skill of efficient communication between teachers and parents. Within this framework, the research questions asked in relation to the research goal are the following:

a) In what way do teachers apply active listening as a basic skill of efficient communication between teachers and parents?

b) What is the contribution of teacher's verbal intervention during active listening as a basic skill of communication between teachers and parents?

c) What are the opinions of teachers about active listening that have an important or strong degree of relevance, in relation to their job position, gender, age or education level?

To respond to the needs of the research approach, the anonymous written closed type of questionnaire was selected as the most appropriate means of collecting data, because it gives the asked teacher the opportunity to reply quickly, honestly and without the fear of immediate control [19]. The questionnaire used in this study is divided into two parts. The first part concerns teachers' personal data and includes job position at school, gender, age, years of experience and studies. The second part, consisting of closed-type questions with five-graded Likert type answers, investigates: a) the way in which teachers apply active listening as a basic skill of efficient communication and b) the contribution of the teacher's verbal intervention during active listening as a basic skill of efficient communication between teachers and parents.

Within the framework of conducting this survey, descriptive statistics indicators were studied, both for categorical variables (e.g., principals, PE70) and for qualitative variables with a rating scale, such as frequency $(\mathrm{N})$, percentage in the total of cases (\%), average value (A), standard deviation (SD). To ascertain there is a correlation between a categorical variable (principals, PE70) and qualitative variables of a rating scale, t-test of independent samples was applied. For the description of statistical significance $p$-value indicator was used. ( $p$-value $<0,01$ : Statistically strong relation, p-value $<0,05$ : Statistically significant relation, $\mathrm{p}$-value $<0,1$ : Statistically weak relation) [20].

It is pointed out that to ascertain the degree of relevance categorical variables of 22-30 years and 51-60 years were selected for age and categorical variables 1-5 years and 26 years or more of experience were selected for the years of experience, in order to ascertain if there is convergence of views among young and senior teachers.

The survey questionnaire was administered to 35 school units, six-classroom and above, in order to ensure that the responses of the sample are characterized by a comparable functioning setting and school atmosphere. Responses to 255 questionnaires in total, by teachers PE70 and principals, were collected. Most of the teachers who filled in the questionnaire were women, aged 41-60, with 16-20 and 26 years or more of experience. Most teachers stated as basic studies the university degree from the Department of Primary Education and as further studies the acquisition of a Master of Science (Table II).

TABLE II: PERSONAL DATA OF TEACHERS AND PRINCIPALS

\begin{tabular}{|c|c|c|c|}
\hline & & $\begin{array}{l}\text { Frequency } \\
(\mathrm{N})\end{array}$ & $\begin{array}{c}\text { Percentage } \\
(\%)\end{array}$ \\
\hline \multirow{2}{*}{ Teachers } & Principals & 33 & 12.9 \\
\hline & Teachers PE70 & 222 & 87.1 \\
\hline \multirow{2}{*}{ Gender } & Men & 71 & 27.8 \\
\hline & Women & 182 & 71.4 \\
\hline \multirow{4}{*}{ Age } & 22-30 years old & 32 & 12.5 \\
\hline & $31-40$ years old & 65 & 25.5 \\
\hline & $41-50$ years old & 84 & 32.9 \\
\hline & $51-60$ years old & 70 & 27.5 \\
\hline \multirow{6}{*}{ Experience } & $1-5$ years & 31 & 12.2 \\
\hline & $6-10$ years & 26 & 10.2 \\
\hline & $11-15$ years & 56 & 22 \\
\hline & $16-20$ years & 59 & 23.1 \\
\hline & 21-25 years & 28 & 11 \\
\hline & 26 years or more & 53 & 20.8 \\
\hline \multirow[b]{2}{*}{ Basic studies } & Pedagogical Academy * & 72 & 28.2 \\
\hline & $\begin{array}{c}\text { Department of Primary } \\
\text { Education } * *\end{array}$ & 179 & 70.2 \\
\hline \multirow{3}{*}{$\begin{array}{l}\text { Further } \\
\text { studies }\end{array}$} & Master & 91 & 35.7 \\
\hline & PhD-Master & 19 & 7.5 \\
\hline & Did not answer & 64 & 25.1 \\
\hline
\end{tabular}

*2 years of studies, $* * 4$ years of studies.

\section{RESULTS}

To the survey question "in what way is active listening applied as a basic skill of efficient communication between teachers and parents", most principals and teachers responded that they always listen to the children's parents 
with attention and observation during their communication. Most principals and teachers responded that most of the times they accept the parent's words without interrupting and adopting a neutral position during the communication taking place between them. In addition, principals and teachers mentioned that most of the times they understand the parent putting themselves into the parent's position, meaning that they apply empathy.

TABLE III: TEACHERS’ Views on APPlying ACTIVE Listening AS A BASIC SKILl of EFFICIENT COMMUNICATION BETWEEN TEACHERS AND PARENTS (Distribution, PERCENTAGE)

\begin{tabular}{|c|c|c|c|c|c|c|c|c|c|c|c|c|c|}
\hline \multirow[t]{2}{*}{ Active listening } & \multirow[t]{2}{*}{ Position } & \multicolumn{2}{|c|}{ Not at all } & \multicolumn{2}{|c|}{ Sometimes } & \multicolumn{2}{|c|}{$\begin{array}{l}\text { I have not } \\
\text { opinion }\end{array}$} & \multicolumn{2}{|c|}{$\begin{array}{c}\text { Most of the } \\
\text { times }\end{array}$} & \multicolumn{2}{|c|}{ Always } & \multicolumn{2}{|c|}{$\begin{array}{l}\text { Did not } \\
\text { reply }\end{array}$} \\
\hline & & $\mathrm{N}$ & $\%$ & $\mathrm{~N}$ & $\%$ & $\mathrm{~N}$ & $\%$ & $\mathrm{~N}$ & $\%$ & $\mathrm{~N}$ & $\%$ & $\mathrm{~N}$ & $\%$ \\
\hline \multirow{2}{*}{ 1. Listening attentively } & Principals & 0 & 0 & 0 & 0 & 1 & 3 & 8 & 24.2 & 24 & 72.7 & 0 & 0 \\
\hline & PE70 & 2 & 0.9 & 1 & 0.5 & 0 & 0 & 52 & 23.4 & 167 & 75.2 & 0 & 0 \\
\hline \multirow{2}{*}{$\begin{array}{l}\text { 2.Acceptance of parent's words } \\
\text { without interrupting }\end{array}$} & Principals & 0 & 0 & 0 & 0 & 2 & 6.1 & 21 & 63.6 & 10 & 30.3 & 0 & 0 \\
\hline & PE70 & 0 & 0 & 23 & 10.4 & 3 & 1.4 & 119 & 53.6 & 77 & 34.7 & 0 & 0 \\
\hline \multirow{2}{*}{ 3.Adopting a neutral position } & Principals & 4 & 12.1 & 6 & 18.2 & 1 & 3 & 13 & 39.4 & 8 & 24.2 & 1 & 3 \\
\hline & PE70 & 11 & 5 & 42 & 18.9 & 5 & 2.3 & 102 & 45.9 & 61 & 27.5 & 1 & 0.5 \\
\hline \multirow{2}{*}{ 4.Empathy } & Principals & 0 & 0 & 3 & 9.1 & 2 & 6.1 & 16 & 48.5 & 12 & 36.4 & 0 & 0 \\
\hline & PE70 & 1 & 0.5 & 19 & 8.6 & 5 & 2.3 & 115 & 51.8 & 82 & 36.9 & 0 & 0 \\
\hline
\end{tabular}

Based on the statistical comparison of the categorical variables and the above questions (see questions 1-4, Table III), there is a degree of relevance only for the categorical variables of age groups 22-30/51-60, 1-5/26 or more years of experience with statements 1 and 4 (Table III).

Principals and teachers aged 22-30 and 51-60, with a strong degree of relevance (significance indicator: $\mathrm{p}=0.003<0.01$ ), consider that they listen to the parents with attention and observation. Moreover, principals and teachers with 1-5 and 26 or more years of experience with a strong degree of relevance $\mathrm{p}=0.005<0.01$, understand and share the reflections and feelings of parents (Table IV).

To the survey question "What is the contribution of the teacher's verbal intervention during active listening as a basic skill of efficient communication between teachers and parents", most principals and teachers responded that always in their verbal communication with parents they first stress the good characteristics of their children and then they point out their difficulties. Principals mentioned that they always ask open-ended and closed-ended clarification questions, while teachers mentioned that most of the times, they adopt this skill of communication with parents. Principals and teachers mentioned that most of the times, they repeat the main positions of the parent, without expressing their personal opinion (Table V).

TABLE IV: TEACHERS' VIEWS ON APPLYING ACTIVE LISTEN AS A BASIC SKILL OF EFFICIENT COMMUNICATION BETWEEN TEACHERS AND PARENTS (STATISTICAL INDICATORS)

\begin{tabular}{cccccc}
\hline \hline $\begin{array}{c}\text { Skills of } \\
\text { efficient } \\
\text { communication }\end{array}$ & A & SD & A & SD & t-test \\
\hline \multicolumn{7}{c}{ 22-30 years old } & $\begin{array}{c}51-60 \text { years } \\
\text { old }\end{array}$ \\
\hline $\begin{array}{c}\text { 1. Listening } \\
\text { attentively } \\
\text { 4. Empathy }\end{array}$ & $\begin{array}{l}\text { 3.41 } \\
\text { 3.56 }\end{array}$ & 0.665 & 4.81 & 0.427 & $0.003<0.01$ \\
\hline \multicolumn{7}{c}{ Years of } \\
experience: $1-5$
\end{tabular}

TABLE V: CONTRIBUTION OF THE TEACHER's VERBAL INTERVENTION DURING ACTIVE LISTENING AS A BASIC SKILL OF EFFICIENT COMMUNICATION BETWEEN TEACHERS AND PARENTS (DISTRIBUTION, PERCENTAGE)

\begin{tabular}{|c|c|c|c|c|c|c|c|c|c|c|c|c|c|}
\hline \multirow[t]{2}{*}{ Verbal and non-verbal positioning } & \multirow[t]{2}{*}{ Position } & \multicolumn{2}{|c|}{ Not at all } & \multicolumn{2}{|c|}{ Sometimes } & \multicolumn{2}{|c|}{$\begin{array}{l}\text { I have } \\
\text { not } \\
\text { opinion }\end{array}$} & \multicolumn{2}{|c|}{$\begin{array}{l}\text { Most of the } \\
\text { times }\end{array}$} & \multicolumn{2}{|c|}{ Always } & \multicolumn{2}{|c|}{$\begin{array}{l}\text { Did not } \\
\text { reply }\end{array}$} \\
\hline & & $\mathrm{N}$ & $\%$ & $\mathrm{~N}$ & $\%$ & $\mathrm{~N}$ & $\%$ & $\mathrm{~N}$ & $\%$ & $\mathrm{~N}$ & $\%$ & $\mathrm{~N}$ & $\%$ \\
\hline \multirow{2}{*}{$\begin{array}{l}\text { 1. Focusing first on the good } \\
\text { characteristics of children, then on } \\
\text { their difficulties }\end{array}$} & Principals & 0 & 0 & 1 & 3 & 1 & 3 & 10 & 30.3 & 21 & 63.6 & 0 & 0 \\
\hline & PE70 & 0 & 0 & 1 & 0.5 & 1 & 0.5 & 75 & 30.3 & 145 & 65.3 & 0 & 0 \\
\hline \multirow{2}{*}{$\begin{array}{l}\text { 2. Open-ended and closed-ended } \\
\text { clarification questions }\end{array}$} & Principals & 0 & 0 & 4 & 12.1 & 2 & 6.1 & 12 & 36.4 & 15 & 45.5 & 0 & 0.5 \\
\hline & PE70 & 0 & 0 & 37 & 16.7 & 6 & 2.7 & 122 & 55 & 56 & 25.2 & 1 & 3 \\
\hline \multirow{2}{*}{$\begin{array}{l}\text { 3. Repetition of main positions } \\
\text { without expressing an opinion }\end{array}$} & Principals & 2 & 6.1 & 5 & 15.2 & 0 & 0 & 21 & 63.6 & 4 & 12.1 & 1 & \\
\hline & PE70 & 21 & 9.5 & 46 & 20.7 & 18 & 8.1 & 102 & 45.9 & 34 & 15.3 & 1 & 0.5 \\
\hline
\end{tabular}

The statistical comparison of the categorical variables also of the above questions (see question 2, Table V) shows a degree of relevance only for the categorical variables man/woman. Men and women in their communication with parents focus first on the good characteristics of their children and then they mention their difficulties with a strong degree of relevance (significance indicator: $\mathrm{p}=0.007<0.01$ ). (Table VI).
TABLE VI: OPINIONS OF TEACHERS ABOUT THE INSUFFICIENT COMMUNICATION BETWEEN PARENTS AND TEACHERS (STATISTICAL INDICATORS)

\begin{tabular}{cccccc}
\hline \hline $\begin{array}{c}\text { Verbal and non- } \\
\text { verbal positioning }\end{array}$ & A & SD & A & SD & t-test \\
\cline { 2 - 4 } $\begin{array}{c}\text { 2. Focusing first on } \\
\text { the good }\end{array}$ & & & & Women & \\
$\begin{array}{c}\text { characteristics of } \\
\text { children and then on } \\
\text { their difficulties }\end{array}$ & 4.46 & 0.605 & 4.69 & 0.510 & $0.007<0.01$ \\
\hline \hline
\end{tabular}




\section{Discussion OF Results}

According to teachers' views on the way of applying active listening as a basic skill of efficient communication between teachers and parents, active listening is applied by paying attention, by accepting the parent's words without interrupting, by adopting a neutral attitude and by showing empathy. These views are supported in a study by [21], which mentions that the teacher must give the parent time to speak and express his/her concerns. During this magic minute of the teacher's silence, the parent unravels his/her reflections and understands that the teacher not only listens to the parent, but he/she is also concerned, puts himself/herself in the position of the parent, respects the parent's opinion.

According to a study conducted by [22], an efficient teacher must be patient and understand the problems of each parent. In this way, the teacher participates in the parent's emotional experience [23]. Reference [11] mention that through the listening skills, the teacher will get the information he/she needs for his/her students, especially those facing learning difficulties. The use of these skills of active listening by the teachers creates a relationship based on trust, genuine interest and mutual respect between teachers and parents [24].

According to the views of teachers in this study about the verbal intervention of teachers during active listening, it seems that teachers in their communication with parents focus first on the good characteristics of the children and then on their weaknesses. In addition, they ask open-ended and closed-ended clarification questions and repeat the parents' main positions. These views are mentioned in a study by [25], who mentions that there are four (4) basic stages in the development of active listening. The teacher: a) asks the parent questions to clarify what was said b) repeats and confirms the parents' words c) informs the parent that he/she understands the parent's concerns and feelings and d) summarizes what was said without expressing a personal opinion. Reference [14] in their study on applying active listening in the communication between teachers and parents ascertained the efficiency of the method 'LAFF Don't CRY' of [9] (Table I).

This study reaches the conclusion that older teachers with 26 or more years of experience listen to parents with attention and observation, understanding their reflections and feelings. In addition, it seems that female teachers in their verbal intervention during active listening focus first on the good characteristics of students and then on their learning weaknesses. Similar results are presented in the study by [26], which confirms the validity and reliability of the Active Listening Attitude Scale (ALAS) in the measurement of listening attitudes of Greek teachers. This study mentions that women are better at using active listening skills and older teachers are more available for communication with parents.

Techers' listening skills are important for a successful communication with their students' parents. References [9], [27] showed in their studies the importance of teachers' training in active listening skills. It is very important for teachers to undergo continuous professional development and optimize their communication skills, so as to achieve efficient communication with the children's parents.

\section{CONCLUSIONS}

The conclusions of this study stress the importance of active listening for the teachers of multi-classroom primary education schools. Teachers listen to children's parents carefully, accept their words without interrupting and adopt a neutral attitude. At the same time, teachers use empathy to put themselves into the parent's position, showing the parent that they understand his/her words. Moreover, teachers in their verbal intervention focus first on the children's good characteristics, leaving their learning weaknesses or poor behavior for the end. Teachers address parents by asking open-ended and closed-ended questions and repeat the basic content of their communication with parents, without expressing a personal opinion.

\section{PROPOSALS}

Based on the results of this study, the beneficial role of active listening as a basic skill of communication between teachers and parents is ascertained. It is suggested to study in the future the presence of active listening as a basic subject in the education or professional development of primary education teachers. Another subject of study could be the presence of active listening as a basic skill of communication between teachers and parents in the education legislation of states.

\section{LIMITATIONS}

Although the number of questionnaires and the percentage of participation of teachers in this survey was satisfactory, the results were not compared with other regions of Greece. The sample is limited to a specific specialization, as all principals and teachers that participated in the survey belong to the same specialization.

This study draws data from my master thesis entitled "Communication management of parent participation in the education process. Views of principals and teachers of primary education schools of Rhodes", which was prepared within the framework of the Master's programme "Design and development modes for school units" of the University of the Aegean.

\section{ACKNOWLEDGMENT}

Sincere acknowledgements to my Professor Panagiotis Stamatis, who contributed to this article with his excellent communication skills and academic knowledge. I would also like to thank the teachers who dedicated their valuable time to fill in the questionnaire. Their view provided the basis of this study.

\section{REFERENCES}

[1] S. E. Saleh. 4Cs in the EFL Classroom. University Bulletin, vol. 4, pp. 57-80, 2019.

[2] M. Grace and CA. Gerdes. "Parent-teacher relationships and parental involvement in education in Latino families". Contemporary School Psychology, vol. 23, no. 4, pp. 444-454, 2019.

[3] L. Mata, I. Pedro and J. F. Peixotoa. "Parental support, student motivational orientation and achievement: The impact of emotions". 
International Journal of Emotional Education. vol. 10, no. 2, pp. 7792, 2018.

[4] P. J. Stamatis (2019). "Communication relations among parents and preschoolers: Thoughts, comments and suggestions", In R. V. Nata (Ed.), Progress in Education, vol. 60, pp. 83-106, USA, NY: Nova Science Publishers.

[5] P. J. Stamatis and M. Chatzinikola. "Advantages and Reasons Hindering the Communication between Teachers and Parents: An Empirical Study". European Journal of Education and Pedagogy. Vol. 2, no. 2, pp. 43-48, 2021.

[6] T. Baker, J. Wise, G. Kelley and R. Skiba. "Identifying barriers: Creating solutions to improve family engagement". Sch. Community J. vol. 26, pp. 161-184, 2016.

[7] B. D. Graham (2019). Listening. In O. Hargie (Eds.) The Handbook of Communication Skills. Fourth edition published 2019 Routledge, 259$286 . \quad$ [Online]. Available: https://dl.uswr.ac.ir/bitstream/Hannan/141245/1/9781138219120.pdf.

[8] P. J. Stamatis. Communication in education and management processes. Athens: Diadrasi, 2012.

[9] D. McNaughton, D. Hamlin, J. McCarthy, D. Head-Reeves and M. Schreiner. "Learning to listen: Teaching an active listening strategy to preservice education professionals". Topics in Early Childhood Special Education, vol. 27, pp. 223-231, 2008.

[10] M. Friend and L. Cook. Interactions: Collaboration skills for school professionals (5th ed.). Boston: Pearson, 2007.

[11] M. Blue Banning, A. J., Summers, C. H. Frankland, L. Lord Nelson and G. Beegle. "Dimensions of family and professional partnerships; Constructive guidelines for collaboration". Exceptional Children, vol. 70, pp. 167-184, 2004.

[12] M.Yasin. "Communication Strategies for Parents and the Community involvement at Integrated Special Education School". International Journal of Humanities and Social Science Invention, vol. 2, no. 4, pp. 6-11, 2013.

[13] K. Diamantidou (2014). "Interpersonal relations in school classroom and skills of efficient communication with students. Education of foreign and repatriated students". [Online]. Available: http://www.diapolis.auth.gr/epimorfotiko_uliko/.

[14] D. R. Castro, A. Cohen, G. Tohar and A. N. Kluger. "The Role of Active Listening in Teacher-Parent Relations and the Moderating Role of Attachment Style”. International Journal of Listening vol. 27, no. 3, pp. 136-145, 2013. DOI:10.1080/10904018.2013.813242.

[15] Chr. Saitis. Initiation of teachers to the secrets of school leadership. Athens: editions Saitis Chr., 2014.

[16] J. Zaki. "Intergrating Empathy and Interpersonal Emotion Regulation". The Annual Review of Psychology, vol.71, pp. 517-540, 2020

[17] D. McNaughton and R. B. Brooks R. Vostal (2010). Using Active Listening to Improve Collaboration With Parents. [Online]. Available: www.researchgate.net/publication/230852814.

[18] G. Reppa (2019). “Active listening based on 'L.A.F.F. don't C.R.Y.' strategy, as a basic tool of efficient communication between teachers and parents". Downloaded from HEPHAESTUS Repository, Neapolis University institutional repository. http://hdl.handle.net/11728/11870.

[19] L. Kidder and C. Judd. Research methods in social relations. Chicago, Holt, Rinehart and Winston Inc, 1986.

[20] M. Linardakis, (2014). P-value. Correlation factors. [Online]. Available: https://opencourses.uoc.gr/courses/mod/page/view.php?id=6671.

[21] S. Lazoritz. "Dealing with angry patients". Physician Executive, vol. 30, no. 3, pp. 28, 2004.

[22] A. Turnbull, R. Turnbull, E. Erwin and L. Soodak. Families, professionals and exceptionality; Positive outcomes through partnership and trust (5th ed) Upper Saddle River, NJ Pearson, 2006.

[23] M. Cole and R. S. Cole. The development of children (4th ed.). New York: Worth Publishers, 2001.

[24] S. Lasky. "The cultural and emotional politics of teacher-parent interactions". Teaching and Teacher Education, vol. 16, pp. 843-860, 2000.

[25] J. Anderson (2008). "Developing active listening skills". IDEA Fitness Journal, vol. 5, no.5, pp. 85-87, 2008.

[26] N. Kourmousi, E. Amanaki, C. Tzavara and V. Koutras. "Active Listening Attitude Scale (ALAS): Reliability and Validity in a Nationwide Sample of Greek Educators". Social Sciences, vol. 6, no. 1, pp. 282017 doi:10.3390/socsci6010028.

[27] K. D. Simmons and C. Hemmings. "The Importance of Integrating Active Listening Skills during Parent-Teacher Conferences in a
Simulated Environment". International Journal of Business Humanities and Technology, vol. 8, no. 1, 2018.

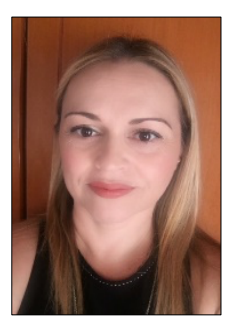

Maria E. Chatzinikola is a Primary Education teacher born in Rhodes Island, Greece. She holds a bachelor's degree from the Department of Primary Education of the University of the Aegean (1994). Also, she holds a Postgraduate Training Diploma in Primary Education from "Alexandros Delmouzos" Teachers' Training Institute (2011) and a master's degree in Models of Educational Planning and Development from the Department of Sciences Preschool Education and Educational Design, University of the Aegean (2019). Currently, she is a PhD student in the field of Nonverbal Communication. 